\title{
Scanning Electron Microscopy and Crystallinity of starches granules from cowpea, black and carioca beans in raw and cooked forms
}

\author{
Joyce Aparecida Tavares de MIRANDA ${ }^{1}$, Lucia Maria Jaeger de CARVALHO ${ }^{1 *}$ (D), \\ Ana Claudia de Macedo VIEIRA ${ }^{1}$, Izabela Miranda de CASTRO ${ }^{2}$
}

\begin{abstract}
Beans are a vital food for the population around the world because it contains a relatively high amount of protein, vitamins, fiber, and minerals, being an important vegetable source of iron, particularly when combined with ascorbic acid and cysteine. The starch content in the seed is between 45 and 60\%. This paper evaluated the granular structure of starches from common beans (Phaseolus vulgaris) and cowpea (Vigna unguiculata) in raw and cooked forms by Scanning Electron Microscopy (SEM), and their crystallinity by X-ray diffraction (DR-X). By SEM, was observed the occurrence of gelatinization phenomenon in cowpea and carioca beans, and the resistance to this event in black beans. By DR-X, the diffraction angles found in this work are more consistent with the classification of the standard polyphorm A. The Relative Crystallinity (RC) of black bean cowpea and carioca beans, observed by X-ray diffraction, varied significantly.
\end{abstract}

Keyword: starch; bean; cowpea.

Practical Application: Physical chemical study of bean and cowpea starches for application in food industries, biocomponds encapsulation, bioplastic and others.

\section{Introduction}

Common beans (Phaseolus vulgaris) is one of the most consumed foods in many countries, containing a relatively high amount of proteins (Los et al., 2018; Rezende et al., 2018). Cowpea beans (Vigna unguiculata) is widely consumed in the North and Northeast of Brazil, as well as some African countries like Nigeria and Burkina Faso, featuring the typical cuisine of these regions (Freire-Filho et al., 2012). As in another species of leguminous plants, the starch content in dry basis in different cultivars of beans is between 45 and 60\%, and therefore, the cooking quality of the beans is associated with postharvest handling and conditions for storage (Ferreira et al., 2017).

The legume starches are digested slowly and have a low glycemic index and are fermented in the large intestine to produce short-chain fatty acids (Kalpanadevi \& Mohan, 2013). Besides the application in the food industry, the starches are industrially applied to the production of biodegradable plastics and nanofilms (Schmidt et al., 2013). As in the other species of starchy legumes, the starch content in the various bean species is between 45 and $60 \%$. The granules shapes are ellipsoidal or spherical, with varying sizes, and contain high amounts of amylose (24 to $65 \%$ ) (Shiga \& Lajolo, 2005). The starch granule is a mixture of amylose and amylopectin polysaccharides, formed by dehydration synthesis.
When viewed microscopically under polarized light shows a typical model of the "Maltese Cross", resulting from birefringence in crystalline regions, which characterizes the radial orientation of the macromolecules. The center of the cross, the hilum, is considered the point of granule growth, and during the bean cooking, it swells irreversibly, losing the structural organization due to the gelatinization. Also, with a long storage time of grains, the gelatinized starches molecules lose the energy and the chains begin to reassociate in a more orderly state, this is called retrogradation phenomenon (Denardin \& Silva. 2009). In legumes, the granules are ellipsoidal or spherical shapes and contain high amounts of amylose (24 to 65\%). They are characterized as compounds, because many granules are in each amyloplast. By Scanning Electron Microscopy (SEM) is possible to observe the presence of some fissure and cracks. The surface of the granules is relatively impermeable to large molecules, such as amylases, due to the severe packaging of amylopectin chain. However, the presence of pores or channels allows the entry of hydrolyzers enzymes and other molecules into the interior. Cracks are related to the low integrity of starches, due to the weak interaction between the amylopectin chains radially arranged (Shiga \& Lajolo, 2005; Martínez-Preciado et al., 2012). The shape and size of granule influence on their functional properties, such as paste viscosity. A high viscosity is desirable for industrial uses, in which the function is the thickener

${ }^{1}$ Programa de Pós-graduação em Ciências Farmacêuticas, Departmento de Produtos Naturais e Alimentos, Universidade Federal do Rio de Janeiro - UFRJ, Rio de Janeiro, RJ, Brasil

${ }^{2}$ Laboratorio de Resíduos e Contaminantes, Centro de Tecnologia e Análises de Alimentos - CTAA, Empresa Brasileira de Pesquisas Agropecuárias - EMBRAPA, Rio de Janeiro, RJ, Brasil

*Corresponding author: luciajaeger@gmail.com 
(Ratnayake \& Jackson, 2008). The diffraction X-ray is used to reveal the presence and characteristic of the crystalline structure of starch. Models of diffraction X-rays are demonstrating that the native starch granules contain between 15 and $45 \%$ crystalline material, which correspond to two polyphorm (A or B) and an intermediate form $(\mathrm{C})$, the classification is based on the content of water and in the double helices of amylopectin packaging configuration (Singh et al., 2003). These patterns of crystallinity depend in part on the length of the amylopectin chains, the packing density within the granules, as well as the presence of water. Starches with type A crystallinity exhibit intensity peaks at $2 \theta$ diffraction angles at approximately $15.3^{\circ}, 17.1^{\circ}, 18.2^{\circ}$ and $23.5^{\circ}$, Type $\mathrm{B}$ at about $5.6^{\circ}, 14.4^{\circ}, 17.2^{\circ}, 22.2^{\circ}$ and $24^{\circ}$, Type $\mathrm{C}$ at about $5.6^{\circ}, 15.3^{\circ}, 17.3^{\circ}$ and $23.5^{\circ}$. There is also a fourth type of crystallinity, type $\mathrm{V}$, formed by the crystallization of amylose with lipids, which shows peaks of intensity at the $2 \theta$ diffraction angles at approximately $12.6^{\circ}, 13.2^{\circ}, 19.4^{\circ}$ and $20.6^{\circ}$ (Lima et al., 2012). Type A crystallinity is described as a highly condensed and crystalline monocyclic cell unit, wherein 12 glucose residues from two-chain in the counter clock wise harbor four molecules of water between the helices. The A-type structure has a chain of amylopectin with lengths of 23 to 29 glucose units. The hydrogen bonding between the hydroxyl groups of the amylopectin molecule is responsible for the formation of the outer helical structure, among which linear chains of amylose moieties are packed through hydrogen bonds with outer chains of amylopectin. This polyphorm occurs in most cereals such as corn, rice, wheat, and oats. The type B pattern structure is more clearly defined, being composed of a basic unit of chains that are packaged in a hexagonal array, where the cellular unit has two double helices in the counter clock wise direction, aligned and arranged in parallel. Type B crystallinity has amylopectin chain lengths of 30 to 44 glucose molecules, containing 36 molecules of water for each 12 glucose residues, being half of that water tightly bound to the double helices, and the other half being concentrated in a screw shaft. In addition to being considered richer in amylose, these types of starch have similar shapes and sizes and are resistant to hydrolysis, both enzymatic and acidic. The C-type structure is an amylopectin intermediate structure, with amylopectin chain lengths between 26 to 29 glucose units, being common in some roots and legumes (Singh et al., 2017; Santiago-Ramos et al., 2018). Starches type A crystallinity are more susceptible to hydrolysis due to the presence of pores on the surface, permeable to certain enzymes, while type B have protective shells, called crystalline blocks. However, type B crystals have a lower melting temperature $\left(77^{\circ} \mathrm{C}\right)$ when compared to crystals type A, $90^{\circ} \mathrm{C}$. (He \& Wei, 2017). This work aimed to evaluate, by SEM, the starch granules present in cowpea beans and common beans in the black and carioca varieties, in raw and cooked forms. Comparing the relative crystallinity of the three varieties of beans through $\mathrm{X}$-ray diffraction.

\section{Materials and methods}

\subsection{SEM}

The samples were raw or cooked in a pressure cooker at $250{ }^{\circ} \mathrm{C}$ for 25 minutes. Before this procedure, the cooked beans were dehydrated at $40{ }^{\circ} \mathrm{C}$ for 18 hours and then stored in a freezer at $-10^{\circ} \mathrm{C}$. After that, it was posted on sheet metal and coated with 30-35 nm of gold at 6.10-2 atm in Balzers sputter Gold Sputter FL9496 Balzers (Liechtenstein). The observations and documentation of the material were carried out at the National Center of Bioimaging of Federal University of Rio de Janeiro (CENABIO - UFRJ) using microscope Zeiss brand EVO MA10 (Germany) tungsten filament, $10 \mathrm{~mm}$ working distance, voltage $-15 \mathrm{kV}$. The images were achieve with Secondary Electron Detector. Starch Isolation The starch extraction was based on the method described by Wang \& Wang (2004) with some modifications. The samples were ground in a laboratory mill (Perten, 3100 ) soaked in $0.1 \% \mathrm{NaOH}$ solution at a ratio of $1: 5$ and to standby for 20 hours. After, the dispersion was subjected to vigorous stirring in a blender for two minutes. The resulting material was passed through a $63 \mu \mathrm{m}$ bolter and centrifuged (Sorvall ${ }^{\circledR}$ RC 6 Plus centrifuge, Thermo Fisher Scientific, Canadian) at $1200 \mathrm{rpm}$ for five minutes at room temperature $\left(25 \pm 2{ }^{\circ} \mathrm{C}\right)$. The supernatant was discarded, and the pellet was resuspended in $0.1 \% \mathrm{NaOH}$ solution then centrifuged again, the operation being performed twice. The extracted starch was dispersed in distilled water and neutralized with $\mathrm{HCl} 1$ mol.L $\mathrm{L}^{-1}$ to $\mathrm{pH} 6.5$ and centrifuged. The pelleted material was resuspended in distilled water and centrifuged, the operation being performed twice. The resulting starch was dried in an oven with air circulation at $40{ }^{\circ} \mathrm{C}$ to $11 \pm 0.5 \%$ moisture. The starch extraction yield was calculated based on the difference between the dry pasta flour before and after the isolation of starch.

\subsection{X-ray diffraction}

Diffraction of X-rays crystallinity tests were performed in the multiuser laboratory of the Chemistry Institute of the Federal University of Uberlândia, using a diffractometer X-ray (XRD-6000, Shimadzu, Brazil), where the scan region of diffraction ranged from $5-30^{\circ}$, with a target voltage of $30 \mathrm{kV}$, current of $30 \mathrm{~mA}$ and the scan speed $1 \mathrm{~min}^{-1}$. The relative crystallinity (RC) of the starch granules was calculated by XRD-6000 software. V. 5.2. The CR values of all bean samples were evaluated by Graphpad PRISM $^{\circledR}$ software, using analysis of variance (ANOVA).

\section{Results and discussion}

\subsection{SEM}

In Figure 1 is possible to visualize the image obtained by SEM of cowpea endosperm. In A, the raw sample with kidney-shaped starches (magnification $5.52 \mathrm{KX}$ ), in B, it is observed irregularities in the starch surface and the presence of cracks (magnification $30.36 \mathrm{KX}$ ), in $\mathrm{C}$, the cooked sample, it is observed that the starch granules are grouped, due to gelatinization phenomenon (magnification 400X), confirmed in D (magnification 19,14 KX).

Salgado et al. (2005a, b) described that in the conditions which are conducted their experiments, the morphology of the starch granules were not influenced by the grain maturation stage. It has kidney-shaped, and the size varied between $11.8 \mu \mathrm{m}$ and $26.7 \mu \mathrm{m}$ with smooth surface, while the pattern of crystallinity was higher in mature than in the green beans. According to the authors, the phenomenon of gelatinization followed by retrogradation can be considered beneficial from 


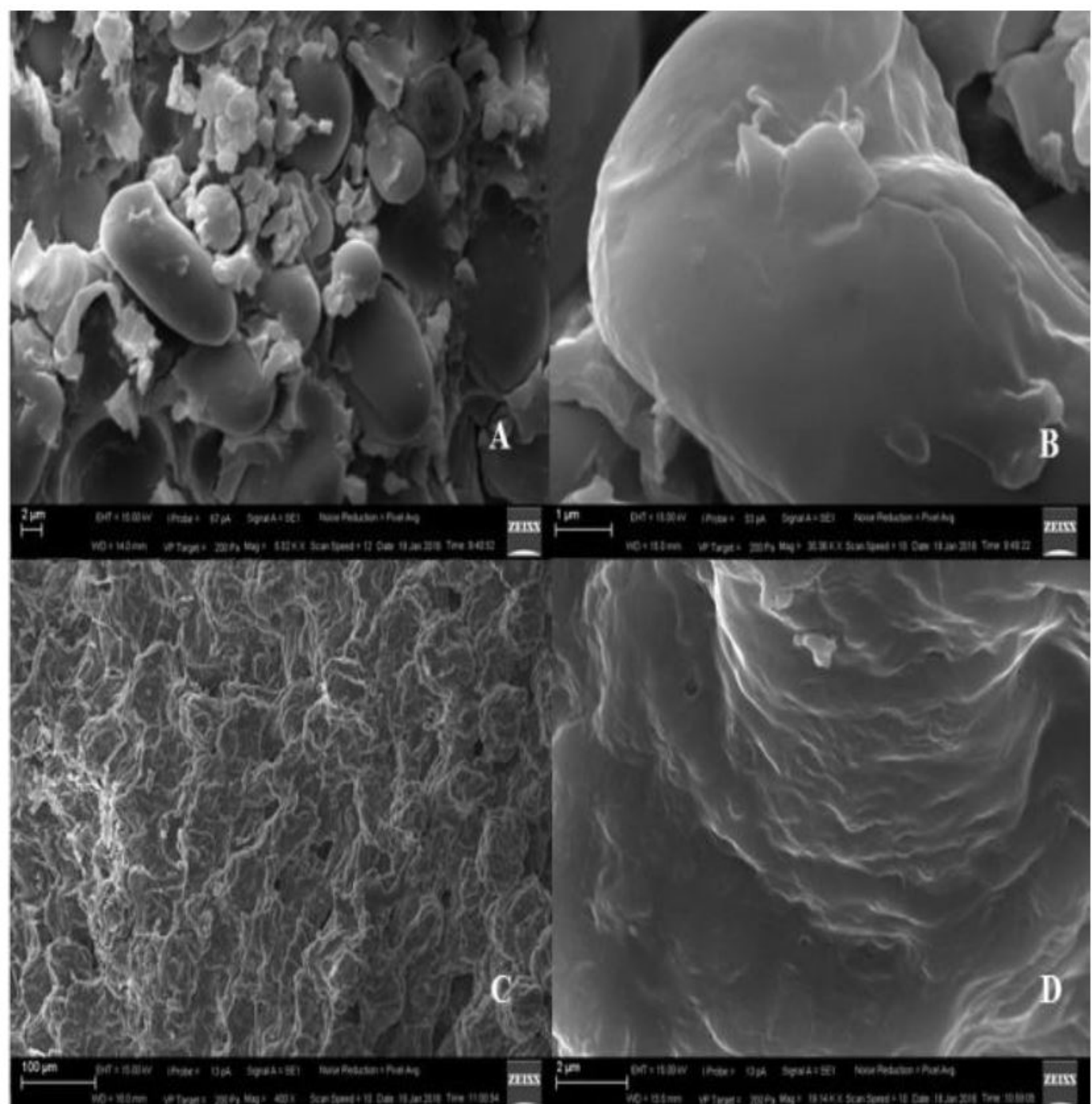

Figure 1. (A) SEM raw cowpea endosperm, magnification $5.52 \mathrm{KX}$; (B) SEM raw cowpea endosperm, magnification $30.36 \mathrm{KX}$; (C) Cowpea cooked with gelatinized starches, magnification 400X; (D) Cowpea cooked cotyledon, magnification of 19.14 KX.

a nutritional point of view by increasing the fiber content. This fact proves a functional property attributed to food, especially considering the role of short-chain fatty acids, produced during the fermentation of resistant starch by bacteria present in the colon. Miranda et al. (2015) observes by Optical Microscopy with polarized light, the empty amyloplasts in cooked cowpea bean, suggesting the lost of birefringence of starches, due to the occurrence of gelatinization.

Figure 2 below shows the SEM of blackbean endosperm. In A, the ellipsoid shape of starches in raw samples (magnification 9.81 KX); in B cracks in the starch surface can be observed (mag. 19.89 KX); in $\mathrm{C}$ is observed cotyledon of cooked black bean (magnifications of $275 \mathrm{X}$ ); in $\mathrm{D}$, is possible to observe that the gelatinization was not complete as in cooked cowpea (Figure 1D), indicating a resistance to this phenomenon, due to the hard-to-cook occurrence (magnification 29.01 KX)

Kaur \& Singh (2007) described the oval shape of blackbean starches and a smooth surface without cracking, observed under normal conditions. Ambigaipalan et al. (2011), by SEM images, also did not find the presence of cracks in black bean starches. Martínez-Preciado et al. (2012) described the morphological structure of common beans starch granules by SEM, observing an irregular oval shape with sizes $10-40 \mu \mathrm{m}$ in length and $10-25 \mu \mathrm{m}$ in width, and small spherical starches of $10 \mu \mathrm{m}$. It was also observed that the starch granules were well-defined and not suffer any damage. Miranda et al. (2015) observed by optical microscopy with polarized light, amyloplasts filled with starches in cooked black bean samples, suggesting that is no gelatinization, due to the occurrence of hard-to-cook (HTC) phenomenon. SEM, however, allows to see that the gelatinization occurs, but partially. At microstructural level, the result of HTC seems to be associated with the inability of the middle lamella of cotyledons cells to dissolve and separate cells. Chigwedere et al. (2018) investigated the relative contributions of cotyledons and seed coats towards hardening of common beans were and the rate-limiting process which controls bean softening during cooking was determined. Fresh or aged whole beans and cotyledons were 


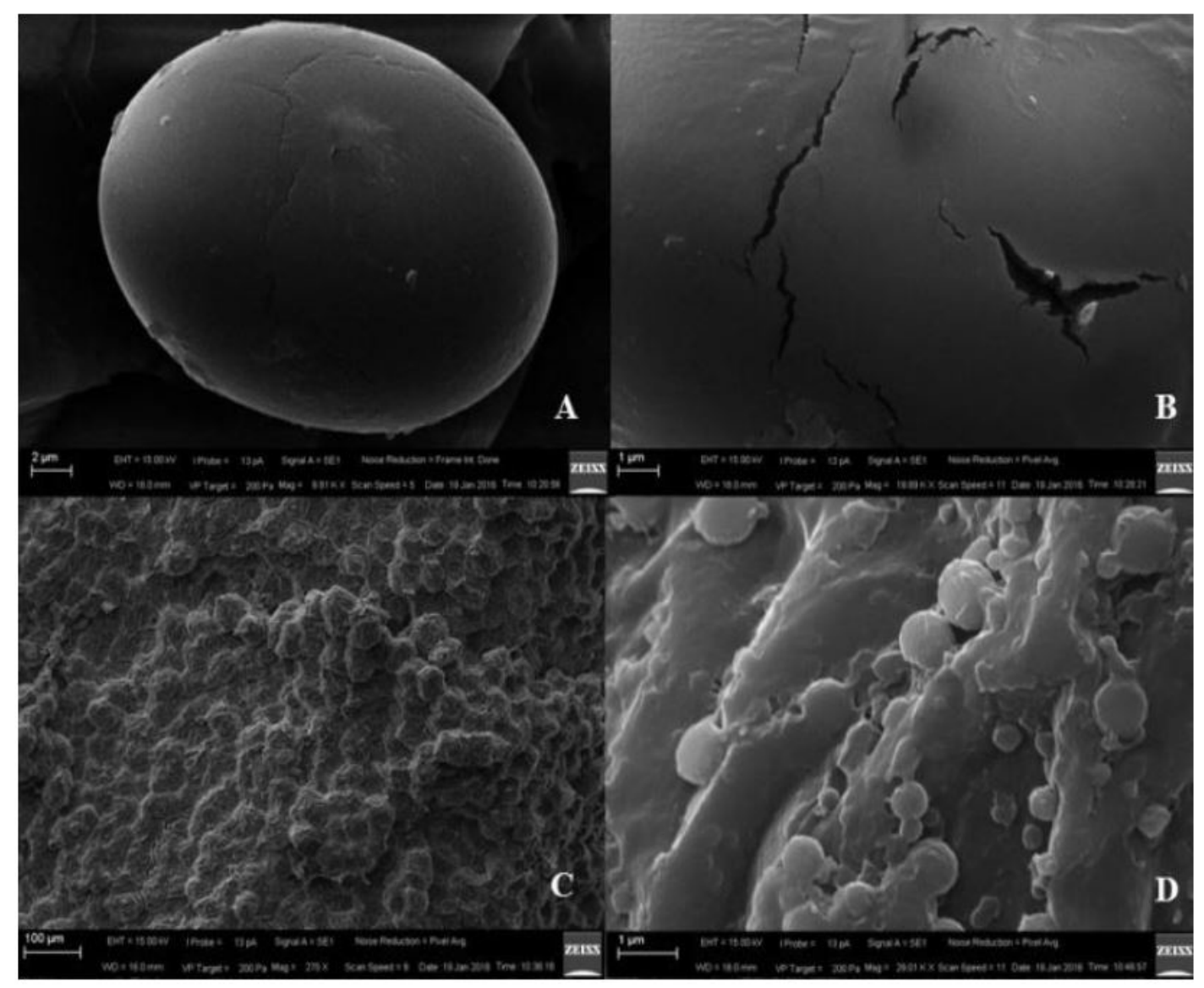

Figure 2. (A) SEM raw blackbean endosperm, magnification 9.81 KX; (B) Raw blackbeans endosperm, magnification 19.89 KX; (C) Cooked black bean cotyledon, magnification 275 X; (D) Cooked black beans without complete gelatinization of starches (magnification $29.01 \mathrm{KX}$ ).

soaked and cooked in demineralised water or $0.1 \mathrm{M} \mathrm{NaHCO}_{3}$ solution, and texture evolution, microstructure changes and thermal properties were studied. The authors suggested that the rate-determining process in bean softening relates to cell wall/middle lamella changes influencing pectin solubilization.

In Figure 3 below, is observed the SEM of carioca bean endosperm. In $\mathrm{A}$, the ellipsoid shape of starches in raw samples, similar to the black bean (magnification 6.00 KX); in B (Figure 2A). In $\mathrm{B}$, it is possible to observe irregularities in the starch surface (magnification 15,61 KX). In C is observed cotyledon of cooked carioca bean (magnifications $370 \mathrm{X}$ ). In $\mathrm{D}$, is observed the gelatinization and no intact chains (magnification $15.61 \mathrm{KX}$ ).

In the work of Ambigaipalan et al. (2011) was not found the presence of cracks in carioca beans starches, as well as in black bean starches, both varieties evaluated by SEM. Wang \& Ratnayake (2014) was observed, by SEM, that has no damage on the starch surface from different Great-Northern bean cultivars. However, some samples had the presence of a strange material. All cultivars showed spherical, oval or elliptical starches shapes. According to the authors, bean starch granules usually have similar morphologies among the varieties of $P$. vulgaris, but unlike other starches such as tapioca and banana. Rupollo et al. (2011) examined SEM starch granules isolated from common bean, stored for 360 days, under three conditions: in hermetically sealed containers at $5^{\circ} \mathrm{C}$, in modified atmosphere with nitrogen at $15^{\circ} \mathrm{C}$ and standard atmosphere at $25^{\circ} \mathrm{C}$. The author observed a great similarity between the granules, even at different storage conditions of seed. However, the starch granules stored in a conventional atmosphere at $25^{\circ} \mathrm{C}$ appeared to be more aggregated than others. The samples stored in modified atmosphere with nitrogen at $15^{\circ} \mathrm{C}$ did not differ in solubility and gel properties over the beans stored in a conventional atmosphere at $25^{\circ} \mathrm{C}$. However, the gel properties of this both conditions, differs from the hermetic samples at $5{ }^{\circ} \mathrm{C}$, which had lower crystallinity, as well as swelling power and gelatinization heat. The starch grains stored in modified atmosphere with nitrogen at $15{ }^{\circ} \mathrm{C}$, in turn, showed lower crystallinity, swelling power, and gelatinization heat than samples stored in a conventional atmosphere at $25^{\circ} \mathrm{C}$. Studies about the effects of storage conditions on bean starch properties are important to understanding the hardening phenomenon (hard-to-cook) and, moreover, make possible a storage standardization for industrial use. Vanier et al. (2014) evaluate the effects of nitrogen-modified atmosphere storage on coat color preservation, and the development of the hard-to-cook 


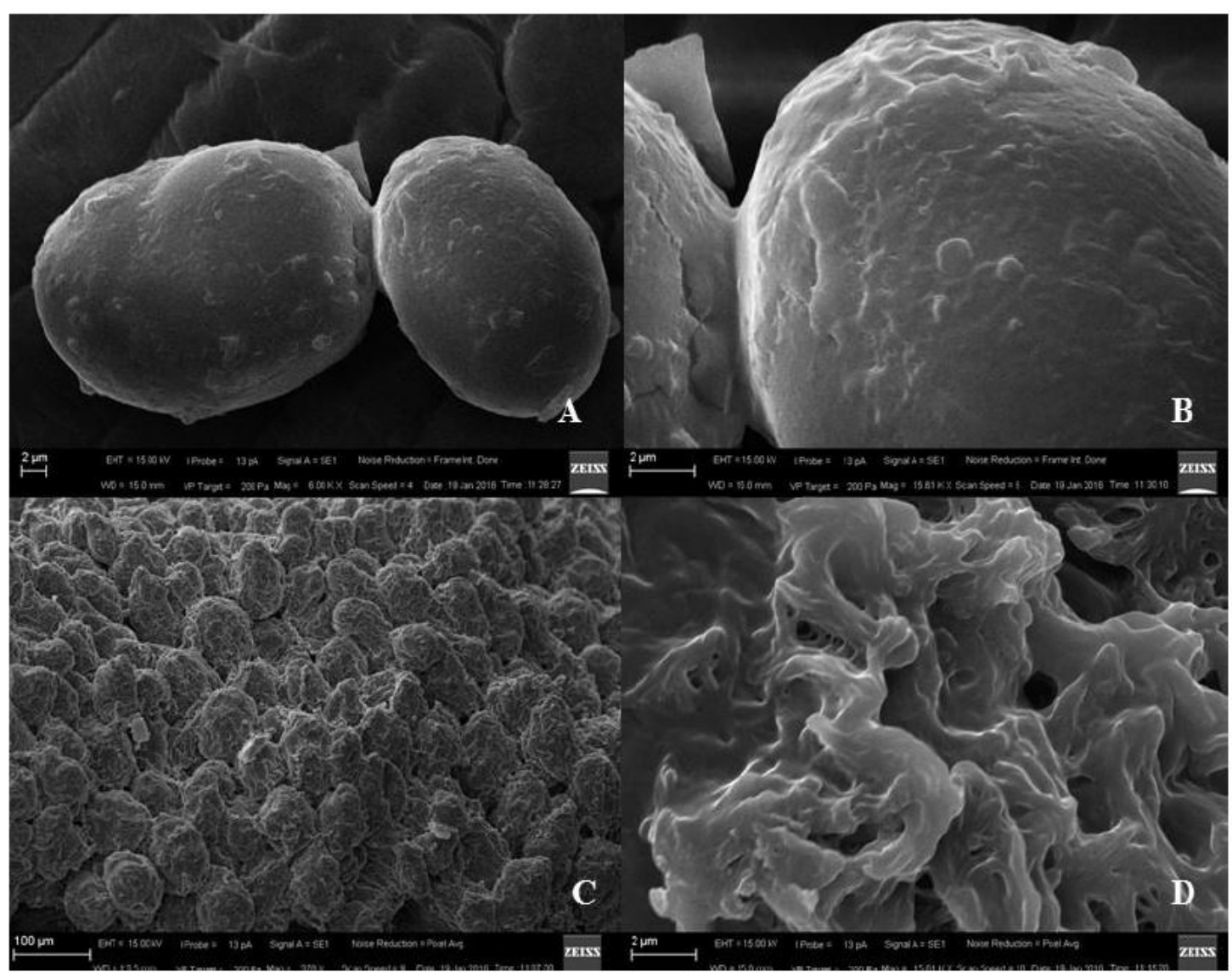

Figure 3. (A) SEM raw carioca bean endosperm, magnification of $6.00 \mathrm{KX}$; (B) Raw carioca bean endosperm magnification $15.61 \mathrm{KX}$; (C) Cooked carioca beans, magnification $370 \mathrm{X}$; (D) Cooked carioca cotyledon, magnification $15.61 \mathrm{KX}$.

defect in Carioca beans stored for 360 days. They observed that this condition of storage preserves the hydration coefficient and the electrical conductivity of carioca bean and slows the development of the HTC defect, at least for 360 days storage. This storage system also reduces the cellular stresses caused by storage in the normal atmosphere at $25^{\circ} \mathrm{C}$. Vanier et al. (2018) characterized starches from four common bean genotypes to use in production of biodegradable films. Starches were characterized by their swelling power, solubility, amylose content, granule morphology, relative crystallinity, thermal and pasting properties, and susceptibility to $a$-amylase hydrolysis. Films were also characterized. The authors observed that depending on the common bean genotype, a great variation on starch properties was found, which, in turn, clearly impacted on the characteristics of the starch-based films.

\subsection{X-ray diffraction}

The properties of X-ray diffraction provides evidence of the ordered structure of the starch granule. According to Figure 4 below, the starches of the common beans and cowpea showed a characteristic of $\mathrm{C}$ pattern, as in general legumes, and peaks of highest intensity in the diffraction regions is in the spacing close at $15^{\circ}$ and $18^{\circ}(2 \Theta)$.

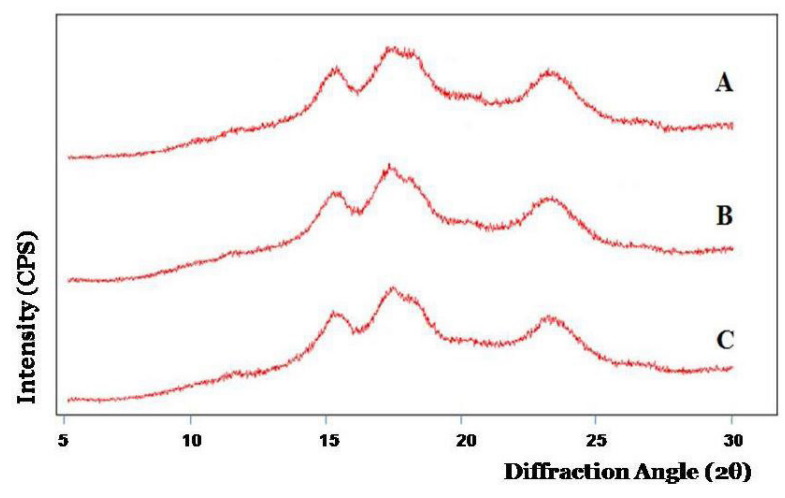

Figure 4. Intensity diffraction peaks of X-ray starch isolated from beans (A) cowpea (B) black, and (C) carioca. CPS: Cont Per Second.

The starch isolated from black beans shows the highest peak values of the three evaluated. The diffraction angles $15^{\circ}, 17^{\circ} 23^{\circ}$ represent the largest of intensity peaks detected in X-ray diffraction, being higher in $17^{\circ}$ for all starches analyzed in this study. Although the literature description generally classifies the crystalline structure of the legume starch in the standard polyform C, the diffraction angles encountered in this work are more consistent with the 
Table 1. Starch yield, Intensity of the main peaks and Relative Crystallinity of starches isolated from cowpea, blackbeans and carioca.

\begin{tabular}{cccccc}
\hline \multirow{2}{*}{ Beans } & Starch & \multicolumn{3}{c}{ Intensity $\left(\mathrm{CPS}^{*}\right)$} & Relative \\
\cline { 3 - 5 } & Yield (\%) & $15^{\circ}$ & $17^{\circ}$ & $23^{\circ}$ & Crystallinity (\%) \\
\hline Cowpea & $15.8 \pm 0.3$ & 1863 & 2214 & 1822 & $10.57 \pm 0.2$ \\
Blackbean & $17.1 \pm 0.2$ & 1938 & 2358 & 1834 & $10.62 \pm 0.3$ \\
Carioca & $16.1 \pm 0.3$ & 1922 & 2306 & 1806 & $10.53 \pm 0.2$ \\
\hline${ }^{*}$ CPS: Cont Per Second. & & & &
\end{tabular}

classification of the standard polyphorm A (Lima et al., 2012; Singh et al., 2017). The yield of isolated starch, the intensity of the main peaks and the relative crystallinity can be observed in Table 1, bellow.

The relative crystallinity following descending order: blackbeans $(10.64 \%)>$ cowpea $(10.57 \%)>$ carioca beans $(10.50 \%)$. Being significantly varied, considering the analysis of variance. According to Hoover \& Ratnayake (2002), differences in relative crystallinity of starches are affected by the size of the crystal. The number of crystalline regions is influenced by the content and length of the amylopectin chain, and the guidelines of the double helices in the crystalline domains, as well as the degree of interaction between double helices.

Pinto (2014) evaluated carioca bean starch subjected to different treatments, and noted the following sequence on the degree of relative crystallinity: enzymatic hydrolysis $>$ native starch $>$ heating $>$ ultrasound $>$ heat treatment of low humidity.

\section{Conclusion}

The SEM method allows observing the difference between the starches of varieties of beans, as well as their modification after beans treatment, like the loss of structural organization, which is characteristic by the gelatinization phenomenon, occurring when the matrix was subjected to temperatures greater than $50^{\circ} \mathrm{C}$. It was also possible to see the occurrence of hard-to-cook phenomenon in blackbean, which would be very important in the supervision of legumes offered for sale and consumption. Regarding the studies of the crystallinity of the starch granules by DR-X, the diffraction angles found in this work are more consistent with the classification of the standard polyphorm A, and the Relative Crystallinity of blackbeans, cowpea and carioca beans, observed by X-ray diffraction, varied significantly, considering a variance analysis.

\section{Acknowledgements}

Cappes, Embrapa-CTAA, CENABIO-UFRJ, IQ-UFU, Laudo Laboratório Avícola.

\section{References}

Ambigaipalan, P., Hoover, R., Donner, E., Liu, Q., Jaiswal, S., Chibbar, R., Nantanga, K. K. M., \& Seetharaman, K. (2011). Structure of faba bean, black bean and pinto bean starches at different levels of granule organization and their physicochemical properties. Food
Research International, 44(9), 2962-2974. http://dx.doi.org/10.1016/j. foodres.2011.07.006.

Chigwedere, C. M., Olaoye, T. F., Kyomugasho, C., Jamsazzadeh Kermani, Z., Pallares Pallares, A., Van Loey, A. M., Grauwet, T., \& Hendrickx, M. E. (2018). Mechanistic insight into softening of Canadian wonder common beans (Phaseolus vulgaris) during cooking. Food Research International, 106, 522-531. http://dx.doi. org/10.1016/j.foodres.2018.01.016. PMid:29579956.

Denardin, C. C., \& Silva, L. P. (2009). Estrutura dos grânulos de amido e sua relação com propriedades físico-químicas. Rural Science, 39(3), 945-954. http://dx.doi.org/10.1590/S0103-84782009005000003.

Ferreira, C. D., Ziegler, V., El Halal, S. L. M., Vanier, N. L., Zavareze, E. R., \& Oliveira, M. (2017). Characteristics of starch isolated from black beans (Phaseolus vulgaris L.) stored for 12 months at different moisture contents and temperatures. Starch, 69(5-6), 69. http:// dx.doi.org/10.1002/star.201600229.

Freire-Filho, F. R., Ribeiro, V. Q., Rocha, M. M., Silva, K. J. D. E., Nogueira, M. S. R., \& Rodrigues, E. V. (2012). Produção, melhoramento genético e potencialidades do feijão-caupi no Brasil. IV Reunião de Biofortificação. Teresina. EMBRAPA, 206, 49.

He, W., \& Wei, C. (2017). Progress in C-type starches from different plant sources. Food Hydrocolloids, 73, 162-175. http://dx.doi. org/10.1016/j.foodhyd.2017.07.003.

Hoover, R., \& Ratnayake, W. S. (2002). Starch characteristics of black bean, chick pea, lentil, navy bean and pinto bean cultivars grown in Canada. Food Chemistry, 78(4), 489-498. http://dx.doi.org/10.1016/ S0308-8146(02)00163-2.

Kalpanadevi, V., \& Mohan, V. R. (2013). Effect of processing on antinutrients and in vitro protein digestibility of the underutilized legume, Vigna unguiculata (L.) Walp subsp. unguiculata. Food Science and Technology (Campinas), 51, 455-461.

Kaur, M., \& Singh, N. (2007). Relationships between various functional, thermal and pasting properties of flours from different Indian black gram (Phaseolus mungo L.) cultivars. Journal of the Science of Food and Agriculture, 87(6), 974-984. http://dx.doi.org/10.1002/jsfa.2789.

Lima, B. N., Cabral, T. B., Neto, R. P., Tavares, M. I. B., \& Pierucci, A. P. T. (2012). Estudo do amido de farinhas comerciais comestíveis. Polímeros, 22(5), 486-490. http://dx.doi.org/10.1590/S010414282012005000062.

Los, F. G. B., Zielinski, A. A. F., Wojeicchowski, J. P., Nogueira, A., \& Demiate, I. M. (2018). Beans (Phaseolus vulgaris L.): whole seeds with complex chemical composition. Current Opinion in Food Science, 19, 63-71. http://dx.doi.org/10.1016/j.cofs.2018.01.010.

Martínez-Preciado, A. H., Estrada-Girón, Y., González-Álvarez, A., Fernández, V. V. A., Macías, E. R., \& Soltero, J. F. A. (2012). Physicochemical, morphological and rheological properties of canned bean pastes "negro Queretaro" variety (Phaseolus vulgaris L.). Journal of Food Science and Technology, 51(9), 1795-1805. http:// dx.doi.org/10.1007/s13197-012-0737-5. PMid:25190834.

Miranda, J. A. T., Carvalho, L. M. J., Vieira, A. C. M., Costa, R. P. C., \& Guimarães, A. L. A. (2015). Anatomical Characterization and Evaluation of Starch Granules in Grain of Black Common Bean and Cowpea Raw and Cooked. Chemical Engineering Transactions, 44, 85-90.

Pinto, V. Z. (2014). Pré-tratamentos na produção de nanocristais de amido de pinhão e feijão (Tese de doutorado). Universidade Federal de Pelotas, Pelotas.

Ratnayake, W. S., \& Jackson, D. S. (2008). Starch gelatinization. Advances in Food and Nutrition Research, 55, 221-268. http://dx.doi.org/10.1016/ S1043-4526(08)00405-1. PMid:18772106. 
Rezende, A. A., Pacheco, M. T. B., Silva, V. S. N. D., \& Ferreira, T. A. P. D. C. (2018). Nutritional and protein quality of dry Brazilian beans (Phaseolus vulgaris L.). Food Science and Technology (Campinas), 38(3), 421-427. http://dx.doi.org/10.1590/1678-457x.05917.

Rupollo, G., Vanier, N. L., Rosa, Z. E., Oliveira, M., Pereira, J. M., Paraginski, R. T., Dias, A. R. G., \& Elias, M. C. (2011). Pasting, morphological, thermal and crystallinity properties of starch isolated from beans stored under different atmospheric conditions. Carbohydrate Polymers, 86(3), 1403-1409. http://dx.doi.org/10.1016/j. carbpol.2011.06.055.

Salgado, S. M., Guerra, N. B., Andrade, S. A. C., \& Livera, A. V. S. (2005a). Caracterização físico-química do grânulo do amido do feijão-caupi. Food Science and Technology (Campinas), 25(3), 259264. http://dx.doi.org/10.1590/S0101-20612005000300022.

Salgado, S. M., Guerra, N. B., Andrade, S. A. C., \& Livera, A. V. S. (2005b). Modificação da concentração de amido resistente em feijão macassar (1. Walp) por tratamento hidrotérmico e congelamento. Food Science and Technology (Campinas), 25, 525-530. http://dx.doi. org/10.1590/S0101-20612005000300022.

Santiago-Ramos, D., Figueroa-Cárdenas, J. D., Véles-Medina, J. J., \& Salazar, R. (2018). Physicochemical properties of nixtamalized black bean (Phaseolus vulgaris L.) flours. Food Chemistry, 240, 456-462. http://dx.doi.org/10.1016/j.foodchem.2017.07.156. PMid:28946298.

Schmidt, V. C. R., Bertib, F., Portob, L. M., \& Laurindo, J. B. (2013). Production of starch acetate films with addition of bacterial cellulose nanofibers. Chemical Engineering Transactions, 32, 2251-2256.

Shiga, T. M., \& Lajolo, F. M. (2005). Cell wall polysaccharides of common beans (Phaseolus vulgaris L.) - composition and structure.
Carbohydrate Polymers, 63(1), 1-12. http://dx.doi.org/10.1016/j. carbpol.2005.06.025.

Singh, B., Singh, J. P., Shevkani, K., Singh, N., \& Kaur, A. (2017). Bioactive constituents in pulses and their health benefits. Journal of Food Science and Technology, 54(4), 858-870. http://dx.doi.org/10.1007/ s13197-016-2391-9. PMid:28303037.

Singh, N., Singh, J., Kaur, L., Singh Sodhi, N., \& Singh Gill, B. (2003). Morphological, thermal and rheological properties of starches from different botanical sources. Food Chemistry, 81(2), 219-231. http:// dx.doi.org/10.1016/S0308-8146(02)00416-8.

Vanier, N. L., de Oliveira, J. P., Bruni, G. P., El Halal, S. L. M., Villanova, F. A., Zavareze, E. D. R., Dias, A. R. G., \& Bassinello, P. Z. (2018). Characteristics of starch from different bean genotypes and its effect on biodegradable films. Journal of the Science of Food and Agriculture, 99(3), 1207-1214. http://dx.doi.org/10.1002/jsfa.929. PMid:30058215.

Vanier, N. L., Rupollo, G., Paraginski, R. T., de Oliveira, M., \& Elias, M. C. (2014). Effects of nitrogen-modified atmosphere storage on physical, chemical and technological properties of Carioca bean. Current Agricultural Science and Technology, 20, 10-20.

Wang, H., \& Ratnayake, W. S. (2014). Physicochemical and thermal properties of Phaseolus vulgaris L. var. Great Northern Bean Starch. Journal of Food Science, 79(3), 295-300. http://dx.doi.org/10.1111/17503841.12357. PMid:24506235.

Wang, L., \& Wang, Y. J. (2004). Rice starch isolation by neutral protease and high-intensity ultrasound. Journal of Cereal Science, 39(2), 291296. http://dx.doi.org/10.1016/j.jcs.2003.11.002. 